\title{
RISK MANAGEMENT OF INDUSTRIAL RADIOGRAPHY PERSONNEL CERTIFICATION ACTIVITIES TO ENSURE WORKER SAFETY AND HEALTH
}

\author{
Ratih Luhuring Tyas ${ }^{1}$, Farah Nurfuadia, Alfitri Meliana \\ 1) Pusat Standarisasi dan Mutu Nuklir (PSMN) Badan Tenaga Nuklir Nasional, Puspitek, \\ Serpong 15314, Indonesia, ltyas@batan.go.id
}

\begin{abstract}
ABSTRAK
PENGENDALIAN RISIKO PADA KEGIATAN SERTIFIKASI PERSONIL RADIOGRAFI INDUSTRI UNTUK MENJAMIN KESELAMATAN DAN KESEHATAN PEKERJA. Meningkatnya pemanfaatan dan pemakaian zat radioaktif dan sumber radiasi lainnya pada industri di Indonesia untuk keperluan uji tak rusak membuat kebutuhan akan radiografer juga bertambah. Dalam menjalankan kegiatan sertifikasi, PSMN memanfaatkan sumber radioaktif berupa sinar gamma dari pesawat sinar-X sehingga pengendalian risiko untuk menjamin keselamatan dan kesehatan peserta perlu diperhatikan. Proses pengendalian risiko yang dilakukan oleh PSMN menggunakan prinsip hierarki pengendalian risiko pada ISO 45001 serta tindakan pencegahan lainnya yang diatur dalam IAEA Safety Guidelines. Tindakan pengendalian risiko di evaluasi secara berkala menggunakan data pembacaan dosis. Berdasarkan hasil pembacaan dosis pegawai dan peserta ujian didapatkan besaran nilai dosis dibawah nilai yang diperbolehkan dengan Nilai Batas Dosis (NBD) tidak lebih dari $20 \mathrm{mSv}$ pertahun. Hal ini menunjukkan bahwa tindakan pengendalian risiko yang telah dilakukan dapat menjamin keselamatan dan kesehatan pekerja pada kegiatan sertifikasi personil radiografi industri di PSMN.
\end{abstract}

Kata kunci: radiografi; radiografer; sertifikasi; pengendalian risiko

\section{ABSTRACT}

RISK MANAGEMENT OF INDUSTRIAL RADIOGRAPHY PERSONNEL CERTIFICATION ACTIVITIES TO ENSURE WORKER SAFETY AND HEALTH. The increasing use of radioactive substances and other radiation sources in the Indonesian industry for non-destructive testing lead to a rise in the need for radiographers. In carrying out certification activities, NQSC utilizes radioactive sources in the form of gamma rays from X-ray appliances. Therefore adequate risk management to ensure the safety and health of participants is needed. The risk management process carried out by PSMN uses the hierarchy principle at ISO 45001 and other preventive measures regulated in the IAEA Safety Guidelines, with the measures evaluated periodically using dose reading data. The dosage results on workers and examinees showed that the dose value is below the allowable value with a Dose Limit Value (NBD) of no more than 20 $m S v$ per year. This means that the risk management measures guarantee workers safety and health in the certification activities of industrial radiography personnel in PSMN.

Keywords: radiography; radiographer; certification; risk management

\section{INTRODUCTION}

The use of radiographic technology for industrial needs in Indonesia is rapidly increasing with a rise in radiographers. Industrial radiography is a technique used to determine the structure and integrity of nondestructive equipment, such as pipes, ships, welded joints, castings, etc [1]. In terms of application, industrial radiography uses an ionizing source in the form of X-ray or gammaray. However, these rays produce which causes injury to humans when exposed for a long time.

Therefore, in carrying out NonDestructive Test activities, it is necessary to employ someone with adequate understanding of the correct and safe use of X-rays or gamma 
radiation sources. A radiation worker or radiographer is authorized to prepare radiographic work using radioactive substances and Ionizing Radiation Generators with a certificate of expertise and at least Level I NonDestructive Test [2].

The Center for Nuclear Standardization and Quality (PSMN) is the only work unit in BATAN that functions to carry out certification and accreditation activities and has established a Person Certification Agency (LSP) accredited by KAN in 2017. LSP-BATAN is tasked with carrying out personnel certification in the field of nuclear energy, such as levels I, II, and III [3]. The certification activity at PSMN BATAN uses an X-ray type YXLON SMART EVO $300 \mathrm{D}$. The use of nuclear or radiation in industrial radiography or certification activities emits radiation that potentially harms workers assuming they are not protected and handled properly [4]. Workers that utilize radioactive sources need protection aimed at preventing radiation doses that arise due to accidental acute and chronic exposures and improper work practices, thereby causing injury. This form of risk management is seen from tool development, application, and procedure review [1].

One of the most popular radiation worker safety control approaches in the industry is the Hierarchy of Risk Controls (HoC). In relation to ISO 45001:2018, HoC plays an important role in safety management planning. The HoC method applies hierarchical risk management based on the assumption of effectiveness in reducing risk [5].

In ensuring the safety of radiation participants and officers in personnel certification activities, LSP BATAN carried out risk management efforts. This process was conducted using a hierarchical risk management approach adopted from ISO 45001:2018 while complying with the safety guidelines issued by the IAEA. This research aims to determine the effectiveness of the risk management hierarchy implementation in personnel certification activities at PSMN BATAN.

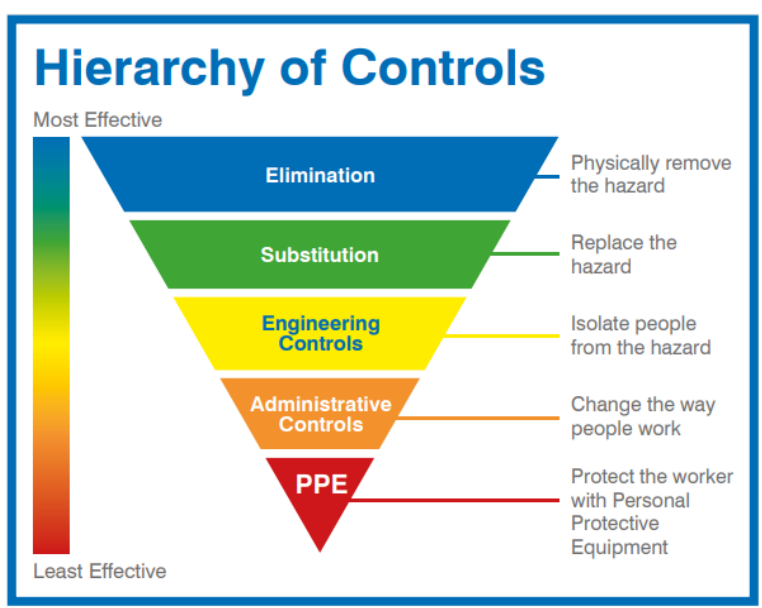

Figure. 1. Hierarchy of Risk Control. Source: ISO 45001:2018 [6]

\section{METHODOLOGY}

Risk management efforts start by identifying management at every engineering, administrative, and PPE level through elimination and substitution. Data were collected on the dose readings of 12 certification officers via batch film for 3 periods in 2019 . These include 31 and 7 examinees on 29-30 April and 29-30 July 2019.

The dose reading results were compared with the limiting values of the examinees and workers. This is also associated with the upper limit for radiation dose on workers and public members that do not exceed the Dose Limit Value (NBD) used in optimizing radiation protection and safety for each use of nuclear power [7]. The last step is to evaluate the management result to determine its effectiveness.

\section{RESULTS AND DISCUSSION}

The identification results of the risk management start from elimination, substitution, engineering, administrative, and PPE. 
Table. 1. Identification of risk management

\begin{tabular}{|c|c|}
\hline Level & Management \\
\hline Elimination & $\begin{array}{l}\text { - Eliminate the use of radiation } \\
\text { equipment }\end{array}$ \\
\hline Substitution & $\begin{array}{l}\text { - Using equipment other than X-ray } \\
\text { machines }\end{array}$ \\
\hline Engineering & Create designs and layouts, \\
\hline Control & $\begin{array}{l}\text { - Install lead on walls according to } \\
\text { design and layout to reduce } \\
\text { exposure. }\end{array}$ \\
\hline Administrative & - Develop a safety program. \\
\hline Control & $\begin{array}{l}\text { - Use of radiation alerts when starting } \\
\text { the X-ray machine in the form of a } \\
\text { 'radiation alert' limit. } \\
\text { - X-ray room light sign that lights up } \\
\text { during usage. } \\
\text { - The existence of a Radiation } \\
\text { Protection Officer (PPR) that } \\
\text { oversees activities, } \\
\text { - Examinees receive safety induction } \\
\text { before entering the X-ray room, } \\
\text { - Monitoring work area and personnel } \\
\text { using survey meter, dosinger, and } \\
\text { TLD }\end{array}$ \\
\hline $\begin{array}{l}\text { Personal Protective } \\
\text { Equipment }\end{array}$ & $\begin{array}{l}\text { - Use labs coat and safety shoes when } \\
\text { working in an X-ray room. }\end{array}$ \\
\hline
\end{tabular}

Table. 2. PSMN's risk management

\begin{tabular}{|c|c|}
\hline Level & Management \\
\hline Engineering Control & $\begin{array}{l}\text { - Creating designs and layouts, } \\
\text { - Install the lead on the wall } \\
\text { according to the design and layout, } \\
\text { at the operator position of } 1 \mathrm{mSV} \text {. }\end{array}$ \\
\hline $\begin{array}{l}\text { Administrative } \\
\text { Control }\end{array}$ & $\begin{array}{l}\text { - Develop a safety program } \\
\text { - The use of radiation signs when } \\
\text { turning on the X-ray machine in the } \\
\text { form of a 'radiation alert' limit, } \\
\text { - X-ray room light sign that flashes } \\
\text { during usage, } \\
\text { - The existence of a Radiation } \\
\text { Protection Officer (PPR) that } \\
\text { oversees activities, } \\
\text { - Examinees receive training before } \\
\text { entering the X-ray room, } \\
\text { - Monitoring the work area using a } \\
\text { survey meter, } \\
\text { - Monitoring of personnel using } \\
\text { dosinger and TLD (this paper is } \\
\text { limited to the data of TLD reading). }\end{array}$ \\
\hline $\begin{array}{l}\text { Personal Protective } \\
\text { Equipment }\end{array}$ & $\begin{array}{l}\text { - Use a lab coat and safety shoes when } \\
\text { working in an X-ray room. }\end{array}$ \\
\hline
\end{tabular}

Some of the actions taken by PSMN in risk management, as shown in Table 1, are not applicable. An instance is an elimination because X-ray machines are a major element in the radiographic personnel certification examination process. Therefore their use cannot be eliminated. The next management action that cannot be applied is substitution. This is because the X-ray machine used has adapted to the type and thickness of the test piece used in the certification exam, therefore, substituting or changing the type of X-ray machine with lower energy creates fear associated with the inability to penetrate the testpiece. Other management actions carried out by PSMN based on the risk management hierarchy are shown in Table 2.

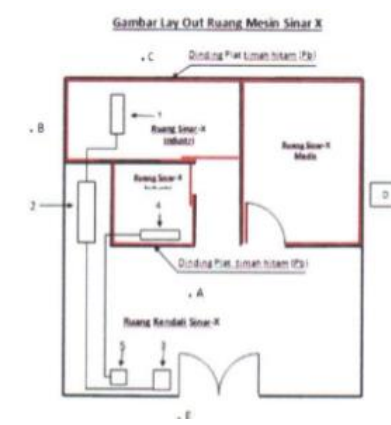

\begin{tabular}{ll}
\hline & \multicolumn{1}{c}{ Picture caption } \\
\hline 1 & X-ray tube machine- merk philips \\
2 & X-ray generator \\
3 & X-ray control panel-merk philips \\
4 & X-ray control panel-merk Y xlon \\
5 & X-ray tube machine-merk Y xlon \\
\hline
\end{tabular}

\begin{tabular}{llllll}
\hline No. & Point & $\begin{array}{c}\text { Radiation exposure } \\
\text { monitoring area }\end{array}$ & $\mathrm{kV}$ & $\mathrm{mA}$ & $\begin{array}{c}\text { Radiation } \\
\text { monitoring } \\
\text { result } \\
(\mathrm{mR} / \mathrm{h})\end{array}$ \\
\hline 1. & $\mathrm{A}$ & Control Panel & 150 & 3 & 0.01 \\
2. & $\mathrm{B}$ & Auditorium & 150 & 3 & 0.00 \\
3. & $\mathrm{C}$ & Backyard & 150 & 3 & 0.00 \\
4. & $\mathrm{D}$ & Women toilet & 150 & 3 & 0.00 \\
5. & $\mathrm{E}$ & Corridor & 150 & 3 & 0.00 \\
\hline
\end{tabular}

Figure. 2. Layout and results of radiation exposure monitoring

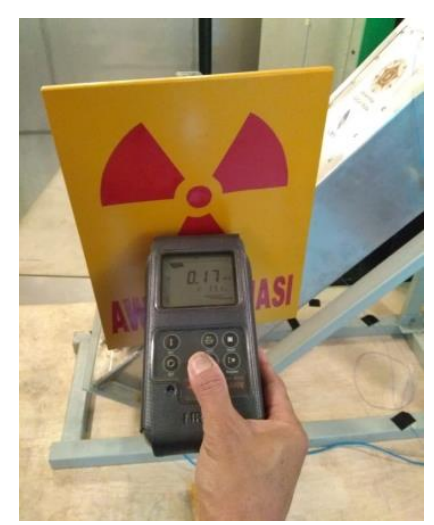

Figure. 3. Radiation Sign and radiation measurement

Regarding personnel safety, one of the management and monitoring actions taken is the use of TLD and the dosinger, which is applicable to the principle of radiation protection. This is capable of reducing the risk of the body receiving radioactive exposure by 
limiting the time of using X-ray machines, increasing the distance from radiation sources, and using shields or PPE. Furthermore, the reading results from the TLD participants and PSMN workers involved in the certification exam activities were recorded and evaluated, as shown in Tables. 4 and 5.

Table. 3. TLD Reading Results for Participant on the certification exam from 29 to 30 April

\begin{tabular}{|c|c|c|}
\hline No & Name & $\mathrm{Hp}(10)$ (mSv) \\
\hline 1 & participant 1 & 0 \\
\hline 2 & participant 2 & 0 \\
\hline 3 & participant 3 & 0 \\
\hline 4 & participant 4 & 0 \\
\hline 5 & participant 5 & 0 \\
\hline 6 & participant 6 & 0 \\
\hline 7 & participant 7 & 0 \\
\hline 8 & participant 8 & 0 \\
\hline 9 & participant 9 & 0 \\
\hline 10 & participant 10 & 0 \\
\hline 11 & participant 11 & 0 \\
\hline 12 & participant 12 & 0 \\
\hline 13 & participant 13 & 0 \\
\hline 14 & participant 14 & 0 \\
\hline 15 & participant 15 & 0 \\
\hline 16 & participant 16 & 0 \\
\hline 17 & participant 17 & 0 \\
\hline 18 & participant 18 & 0 \\
\hline 19 & participant 19 & 0 \\
\hline 20 & participant 20 & 0 \\
\hline 21 & participant 21 & 0 \\
\hline 22 & participant 22 & 0 \\
\hline 23 & participant 23 & 0 \\
\hline 24 & participant 24 & 0 \\
\hline 25 & participant 25 & 0 \\
\hline 26 & participant 26 & 0 \\
\hline 27 & participant 27 & 0 \\
\hline
\end{tabular}

\begin{tabular}{ccc}
\hline No & Name & Hp (10) (mSv) \\
\hline 28 & participant 28 & 0 \\
29 & participant 29 & 0 \\
30 & participant 30 & 0 \\
31 & participant 31 & 0 \\
\hline
\end{tabular}

Table. 4. TLD reading results for participants on the certification exam from 29 to 30 July 2019

\begin{tabular}{clc}
\hline No & Name & Hp (10) (mSv) \\
\hline 1 & participant 1 & 0 \\
2 & participant 2 & 0 \\
3 & participant 3 & 0 \\
4 & participant 4 & 0 \\
5 & participant 5 & 0 \\
6 & participant 6 & 0 \\
7 & participant 7 & 0 \\
\hline
\end{tabular}

Description:

- A value of 0 is not detected or below the minimum detection limit

- The minimum detection limit of $0.03 \mathrm{mSv}$

- Dose Limit Value (NBD) per year effective dose is $20 \mathrm{mSv}$ and $500 \mathrm{mSv}$

- The test method used refers to Safety Guide No RS-G-1.3, IAEA (1999)

The test participant's TLD reading data from 29 to 30 April 2019 and 29 to 30 July 2019 showed that all participants had a mobile value (10) of $0 \mathrm{mSv}$. Meanwhile, the reading of PSMN workers involved in certification exam activities on 3 periods in 2019 is shown in Table 5:

Table. 5. TLD reading results for PSMN workers in 2019

\begin{tabular}{|c|c|c|c|c|}
\hline \multirow[t]{2}{*}{ No } & \multirow[t]{2}{*}{ Name } & $\begin{array}{c}\text { Period } \\
\text { March } 1 \text { - May } \\
31\end{array}$ & $\begin{array}{c}\text { Period } \\
\text { June } 3 \text { - August } 30\end{array}$ & $\begin{array}{c}\text { Period } \\
2 \text { September - } 30 \text { November }\end{array}$ \\
\hline & & \multicolumn{3}{|c|}{$\mathrm{Hp}(10)(\mathrm{mSv})$} \\
\hline 1 & worker 1 & 0 & 0.03 & 0.03 \\
\hline 2 & worker 2 & 0 & 0 & 0 \\
\hline 3 & worker 3 & 0 & 0 & 0 \\
\hline 4 & worker 4 & 0 & 0 & 0 \\
\hline 5 & worker 5 & 0 & 0 & 0 \\
\hline 6 & worker 6 & 0 & 0 & 0.05 \\
\hline 7 & worker 7 & 0 & 0 & 0 \\
\hline 8 & worker 8 & 0 & 0 & 0 \\
\hline 9 & worker 9 & 0 & 0 & 0 \\
\hline 10 & worker 10 & 0 & 0 & 0 \\
\hline 11 & worker 11 & 0 & 0 & 0 \\
\hline 12 & worker 12 & 0 & 0 & 0 \\
\hline
\end{tabular}

Description:

- A value of 0 is not detected or below the minimum detection limit

- The Dose Limit Value (NBD) per year is 20 $\mathrm{mSv}$
- NBD for skin organs per year is $500 \mathrm{mSv}$

- The test method used refers to Safety Guide No RS-G-1.3, IAEA (1999) 
Based on the worker TLD reading results for these 3 periods, it was concluded that, although there are some workers with a value of more than $0 \mathrm{mSv}$, it was still below the dose limit set yearly, namely $2 \mathrm{mSv}$. Therefore, the risk management measures have been prepared to maintain safety and worker health. The value of $2 \mathrm{mSv}$ was obtained from the approach used to obtain maximum exposure of 0.05 $\mathrm{mSv} /$ quarter. This cumulates in a dose of 0.2 $\mathrm{mSv}$ within a year. The dose limit is set at 10 times the largest dose received in a year. The worker TLD readings carried out for 3 periods or equivalent to 9 months do not exceed the annual dose limit. For participants, the dose of the TLD reading is the radiation taken during the 2-day certification exam.

\section{CONCLUSION}

In conclusion, the risk management actions carried out by PSMN and the results of TLD readings for both participants and workers are essential and effective in carrying out the personnel certification exam activities and in maintaining the safety and health of participants and workers. From the data obtained, it is concluded that the average radiation dose absorbed by participants and PSMN workers are $0 \mathrm{mSv}$, and $0.0092 \mathrm{mSv}$, respectively. The highest dose absorption owned by Worker 1 for 3 periods in 2019 is $0.06 \mathrm{mSv}$. This is because PSMN workers, apart from being involved in certification exam activities that use $\mathrm{X}$-rays, also carry out other activities that allow for larger dose absorption from other workers and participants with predetermined values. This is achieved because the preventive actions taken by PSMN have been optimal. Furthermore, the need to apply a risk culture to the company reduces the number of accidents in the company. Risk culture is the behavioral attitude of both individuals and organizations in preventing management actions [8]. Therefore, to further optimize risk management and ensure the safety and security of PSMN workers, it needs to be internalized with the mandatory participation in the certification exam at PSMN.

\section{REFERENCES}

1. IAEA, "Safety Report Series: Radiation Protection and Safety in Industrial Radiography," IAEA, Vienna, 1999.

2. BAPETEN, Peraturan BAPETEN Nomor 8 Tahun 2014, Jakarta: BAPETEN, 2014.

3. BATAN, "batan.go.id," BATAN, 3 August 2017. [Online]. Available: http://www.batan.go.id/index.php/id/kedep utian/standardisasi-mutu-nuklir/3556-batanditetapkan-sebagai-ls-person-oleh-kan. [Accessed 295 2020].

4. Directorate Radiation Control, Code of Practice for Industrial Radiography (Gamma Radiography), South Africa: Department of Health Republic of South Africa, 2019.

5. M. F. P. M. D.-W. Elisa G Liberati, "Learning from high Risk Industries may not be Straightforward: A Qualitatve Study of the Hierarchy of Risk Controls Approach in Healthcare," International Journal for Quality in Health Care, vol. 30, no. 1, pp. 3943, 2018.

6. NQA, ISO 45001:2018 Occupational Health and Safety Implementation Guide, Dunstable: NQA, 2018.

7. BAPETEN, Peraturan Kepala BAPETEN Nomor 4 Tahun 2013 tentang Proteksi dan Keselamatan Radiasi dalam Pemanfaatan Tenaga Nuklir, Jakarta: BAPETEN, 2014.

8. Dharu Dewi, "Penerapan Sistem Manajemen Risiko pada Industri Nasional Sebagai Masukan untuk Program PLTN," Prosiding Seminar Nasional Pengembangan Energi Nuklir V,2012. 
Jurnal Forum Nuklir, Volume 14, Nomor 2, November 2020 